\title{
PASTURE FOR HORSES: AN UNDERESTIMATED LAND USE CLASS IN AN URBANIZED AND MULTIFUNCTIONAL AREA
}

\author{
K. BOMANS, V. DEWAELHEYNS \& H. GULINCK \\ Department of Earth and Environmental Sciences, K.U.Leuven, Belgium.
}

\begin{abstract}
This paper investigates the spatial importance of horses in a multifunctional and urbanized area. The growing spatial importance of horses in the open space was already mentioned by different authors, but never quantified before. In many countries, including Belgium, statistics on horses are only partly covered by agricultural data. As a consequence, the amount of space in use for horses, especially hobby horses, is largely unknown but may encompass a significant area of the open space. Especially within the context of an increasing urbanization and growing demands on the remaining rural area, this evolution must not be neglected. A reliable quantification of the space used by horses is therefore essential and is given in this research for the case study Flanders. According to the results of fieldwork, about one-third of the pasture land in Flanders is used to keep horses. A qualitative analysis showed a higher horse density within the more urbanized areas with a fragmented agricultural area and a quantitative analysis showed negative associations between the presence of horses and (i) the distance to gardens, (ii) the parcel area and (iii) the distance to forest. Moreover, an internet survey assessed evolutions and motivations of horse owners to keep horses. The survey resulted in clear data on the fact that the number of horses is increasing. This is mainly motivated by recreational purposes. The majority of horsekeepers do not consider themselves to be part of the agricultural sector. These results, showing an intensified competition for land between stakeholders in the open space of urbanized regions put new challenges for sustainable land use planning. The major challenges are (i) to avoid increasing functional and spatial fragmentation of rural landscapes, (ii) to assure enough space for societal necessity urgencies such as food or energy selfefficiency, (iii) to increase positive interactions of horse keeping with other sectors such as agriculture, nature conservation and others and (iv) to develop a proper visual and cultural landscape strategy, helping in setting up guidelines for fencing and other infrastructural elements that do not deteriorate the landscape character. Keywords: internet survey, Land use, land use change, multifunctionality, pasture for horses, urban areas.
\end{abstract}

\section{INTRODUCTION}

More and more, former agricultural land is used for horses covering a range of functions (sport, recreation, breeding ...). Up till now, very little information is available on the spatial importance of horses. In many countries, including Belgium, statistics on horses are only partly covered by agricultural data. As a result, the amount of space in use for e.g. hobby-horses and its evolution could never be quantified properly. However, this land use can take up a significant amount of space and can have consequences for the functioning of the land and the rural economy [1]. Moreover, possible associations between the presence of horses and environmental characteristics like urbanization [2] were never quantified before. Therefore, this paper tries to investigate the spatial importance of horses for the case study Flanders. More specifically, we try to answer the following questions:

- What is the amount of space used for horses in Flanders?

- Which associations can be found between the presence of horses and environmental characteristics?

- To what extent can we talk about 'horsification' and what is the underlying motivation for this evolution?

To answer these questions, the paper starts with a short literature review to situate the subject in a Flemish as well as an international context. Next, the spatial importance of horses 
is estimated using fieldwork in six municipalities in Flanders. Using logistic regression, the spatial distribution is related to environmental characteristics, including among other things like urbanization, distance to gardens and forests and fragmentation. The evolution in number of horses and related land use changes are then examined based on an internet survey filled in by 1001 horse holders. In the survey, evolution in numbers of horses, use of space and motivations of horse holders are questioned. Finally, the evolution of horsification is discussed within the context of sustainable development and planning in a multifunctional and urbanized environment.

\section{LITERATURE REVIEW}

\subsection{Economic context}

In the past, horses were used worldwide as draught horse not only in agriculture, mines, forestry, and ports, but also in the army, and for private and public transport. After WWII horse power was substituted for motorization. For example, according to the agricultural statistics of Sweden, the number of draught horses diminished from 9,457 horses in 1901 to 0 horses in 1976 [3]. In Belgium, there were up to 200,000 draught horses in 1950. In 1960, the number declined to 157,350 (compared to 43,000 tractors) and to 16,258 in 1983 (compared to 120,000 tractors). Now (in 2009) there are around 15,000 draught horses left, mainly used for recreational purposes (www.trekpaard. be). While in the past the economic importance of horses was strongly linked to those draught horses, it has now shifted towards production, trade and use of riding and breeding horses. According to Viaene [4] and Policy Research Cooperation [5], the horse sector has a significant economic importance in Flanders. The sector generates an annual added value of 215 million and employment for 3,500 full time equivalents.

\subsection{Social context}

More and more people keep one or more horses for recreational purpose. Already in 1986, Daniels discussed the growing number of hobby-farms within the urban-rural environment of Oregon. In Finland, horse riding is an increasing recreational activity [6]. Viaene et al. [4] point to the growing interest in Belgium for recreational horse riding and driving. The same can be said about Sweden, where Myhr and Johansson [2] notice the link with the proximity of urban areas. In the case study of Busck et al. [7], the number of hobby-related animal units increased from 0.02 to 0.1 per ha between 1984 and 2004 in Denmark. In Flanders, according to VLM [8] around 200,000 people ( $3 \%$ of the entire population) are horse riders.

\subsection{Spatial context}

There is not much existing information on the spatial importance of horses. According to Van der Windt et al. [9], the Netherlands count around 400,000 horses. For Belgium, Viaene et al. [4] estimated the number of horses, donkeys and ponies at 160,000, taking up an area of around 69,500 ha. But now, experts estimate the number for Belgium to be around 200,000 (150,000 in Flanders). However, these are rough estimations and Verburg et al. [1] notice that in many countries hobby-horses are not considered by agricultural statistics. Therefore, the number of and the area for horses are largely unknown. 


\subsection{Horsification}

Recently, some rather strange sounding terms like 'horsification' or 'horsiculture' popped up, especially in the Netherlands [9], referring to the growing number of horses. But also in Flanders the attention for the horse-sector grew, as in 2008 the Flemish government organized a series of stakeholder workshops to shed more light upon this sector. Veijre [10] mentioned 'horsification' to be a striking evolution in Denmark also, and Verburg et al. [1] talk about the growing area of pasture for horses in Western Europe.

Some of the causes of this horsification can be found in the economical strength of the sector. In some places, maneges replace agricultural enterprises, and production of crops or animals is no longer the objective. Another explanation could be found in the diversification of farms, where farmers develop alternative activities on their farm [7], e.g. renting land for horses.

Although horsification is a quite unknown evolution and there are no clear quantitative data existing, people express already positive as well as negative perceptions on this evolution. According to van der Windt [9] horseholdings could give a new stimulus to rural development and recreation. The opening up of an area for walkers and bikers could go hand in hand with the establishment of pathways for horse riders. He also notices that the small-scale parcel structure, related to horse-holdings, offers opportunities for the environment when special attention is given to small landscape elements on these parcels. However, different people talk about negative aspects, linked to horses and horse riding. For example Törn et al. [6] stress the negative impacts of the recreational pressure of horse riding on the environment, like condensation of the soil, damage of vegetation and a changing plantcomposition due to the introduction of foreign seeds. Verburg et al. [1] on the other hand talk about the 'lumber' appearing into the landscape, referring to different artificial elements like buildings and fences. Finally, horsification is considered as a threat for the agricultural sector. For example, Daniels [11] states that hobby-farmers cause an increase in the land prices, because they are willing to pay more for a small parcel of land and they also contribute to further fragmentation of the open space leaving fewer opportunities left for the professional farmers.

\section{METHODS}

\subsection{Study area}

Flanders, the northern part of Belgium (Fig. 1), is known as an example of a strongly urbanized region, characterized by urban sprawl.
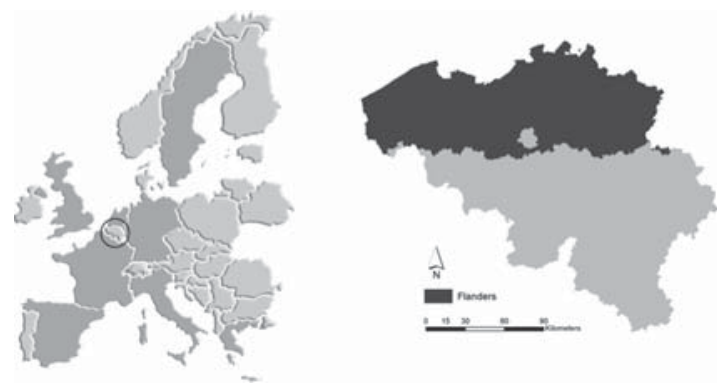

Figure 1: Location of the study area Flanders. 
With a population density of 447 inhabitants per $\mathrm{km}^{2}$ in 2007, it is one of the most densely populated regions in Europe. Only 10\% of Flanders is defined as rural according to the OECD criterion of 150 inhabitants per $\mathrm{km}^{2}$ measured at basis district level (municipalities). Data from Eurostat indicate that the average road density in Flanders is $4.7 \mathrm{~km} / \mathrm{km}^{2}$, much higher than the average for Europe $\left(1.2 \mathrm{~km} / \mathrm{km}^{2}\right)$. However, looking through the eyes of a Flemish inhabitant, rural open space is not solely present in those rural $10 \%$ of the area. Agricultural land encompasses more or less $45 \%$ of Flanders' surface, but it is for a large part spatially fragmented and interwoven with or in close proximity to other functions like housing, infrastructure and industry. This makes the Flemish open space not only a production space for agriculture and forestry but also an ecological space for nature. The ubiquity of urbanization adds a growing consumption function to the rural open space, like recreation for both dwellers and visitors or an attractive setting for (new) residential dwellings. Moreover, the open space is a buffering medium that prevents or mitigates environmental problems such as biodiversity loss, erosion, flooding, different forms of pollution and visual and acoustic impacts of development. This intertwining of different functions is both cause and effect of fragmentation and multifunctionality in the Flemish open space.

Since 2008, owners of one or more horses (including donkeys and ponies) have to register their horse(s) at the Belgian Confederation for Horses (BelCoHorse). These data are available at the level of a municipality. Because this registration has started recently, it can be assumed that this data source is not complete and that many people still have to register their horse(s). In February 2009, the number of horses registered counted almost 106,000. The spatial distribution of the horses in Flanders according to these data is presented in Fig. 2. The lower the number in the right figure, the more the existing pasture is used for other animals/activities than horses.

\subsection{Case studies}

Because the census data are incomplete, extra field work is carried out in six Flemish municipalities (i) to give a reliable estimation on the spatial importance of horses in Flanders and (ii) to quantify associations with environmental characteristics.

\subsubsection{Cluster analysis}

It is important to consider different parts of Flanders with different environmental characteristics to prevent a distorted result due to biased sampling. To define the case studies, a cluster analysis was carried out in SPSS 15.0, based on the following environmental characteristics:

- Urban characteristics: inhabitants per municipality and \% built area.

- Agricultural characteristics: area\% of different production activities (horticulture in open air, greenhouses, fruit orchards, arable farming (excluding fodder crops), cattle breeding, pasture and fodder crops).

- Fragmentation of agricultural parcels: Perimeter/Area.

- Forest characteristics: Forest index.

The cluster analysis used, is a K-means clustering. This is a non-hierarchical way of clustering in which $\mathrm{k}$ refers to the number of clusters. After standardization, the data are divided into $\mathrm{k}$ initial clusters. For each observation, the distance to the cluster centre is measured and observations are, if necessary, replaced to another - nearer - cluster, after which the cluster centers are calculated once again. These steps are repeated until no more re-allocation of data takes place [12]. This cluster analysis results in groups of municipalities with similar environmental characteristics. By taking 


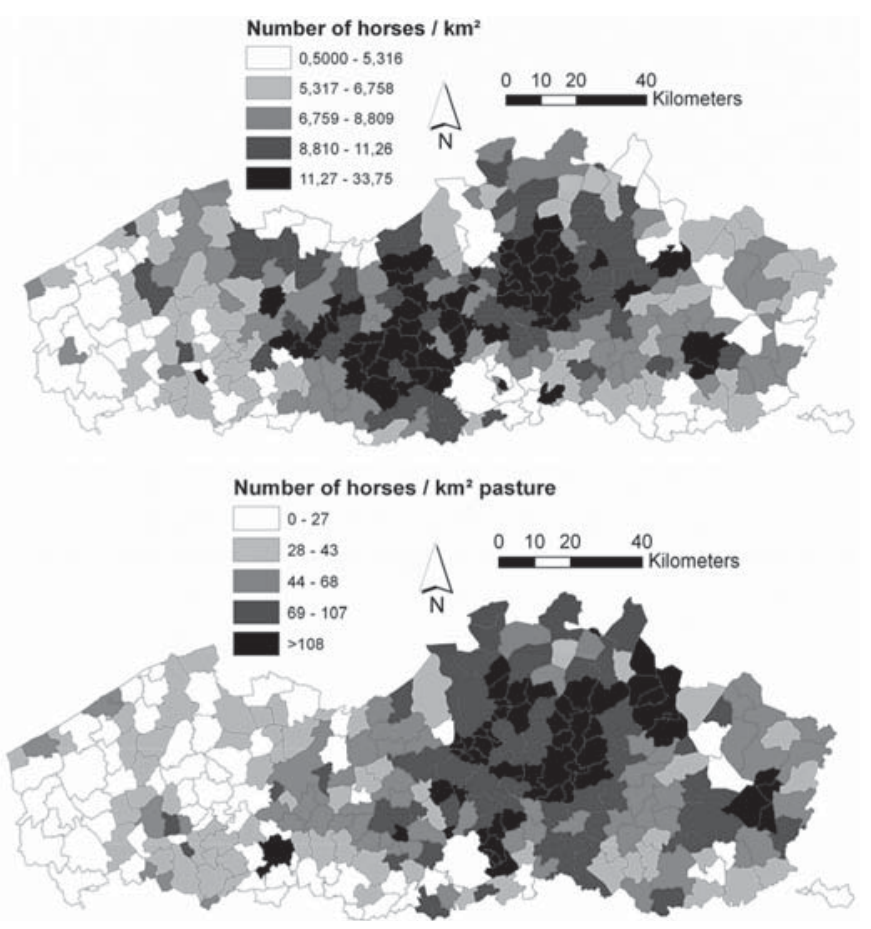

Figure 2: Number of horses per municipality, expressed per $\mathrm{km}^{2}$ (above) and per $\mathrm{km}^{2}$ of pasture land (below).

these clusters into account in the selection of the case studies, a variation in urban, agricultural, fragmentation and forest characteristics in Flanders is taken into account from the beginning. For each cluster, at least one municipality was demarcated as case study area. The result of the cluster analysis including the selected municipalities is presented in Fig. 3.

The horse density, calculated with the census data, is averaged per cluster to give a qualitative analysis on the association between horse density and environmental characteristics.

\subsubsection{Sampling per case study}

Because a total inventory of pastures for horses within the six municipalities was practically impossible due to time limits, a sample of segments was selected. The form of the segments can be determined by natural bounders, parcel bounders, roads or uniform segments [13]. To keep a good comparability between the segments of the different study areas, we chose to use square segments. Another advantage is that this is a fast and cheap way to define a sample of segments [14]. The segments were randomly distributed throughout each case study. Because the cluster analysis can be considered as a form of stratification, there is no further division within one case study.

Theoretically, the ideal size of a segment is the one that gives the highest certainty and the lowest costs [15]. Practically, this is difficult to decide, because the optimal size is related to different factors like goals of the research, costs, variability between segments, accessibility, availability of data, etc. [16]. The scale of the landscape under investigation determines for a big part the size of the segments. In general, small segments correspond to small parcels, an intensive agriculture and urban landscape, big segments with a more extensive landscape [13]. For complex landscape, the 


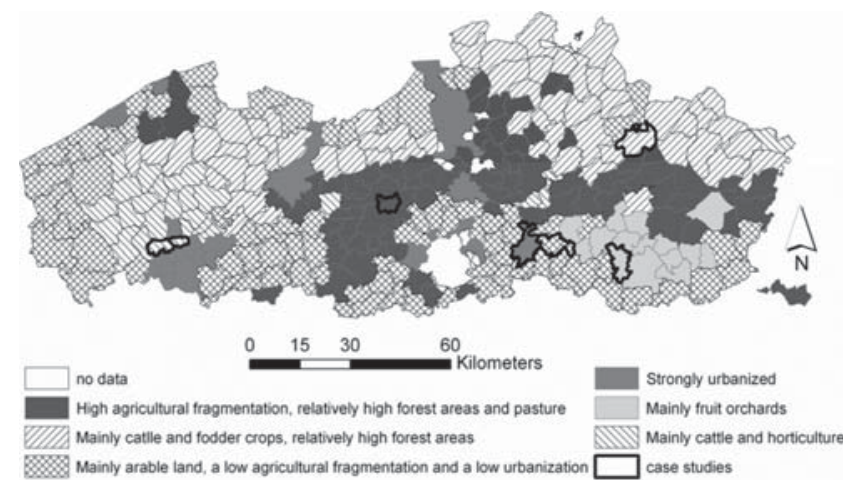

Figure 3: Selection of the case studies within the clusters (from left to right): Lendelede-Ledegem, Lebbeke, Leuven, Lubbeek, Zoutleeuw and Balen.

size of 25 ha is used $[17,18]$ and this size is generally smaller than the segments used in different landscape-ecological and land use studies (MARS (25-200 ha) in Gallego [19]; Countryside survey $\left(1 \mathrm{~km}^{2}\right)$ in Bunce et al. [20]; Bunce et al. [17] (1 km²); Sepp [21] (450-1200 ha), Rondeux et al. [22] $\left(1 \mathrm{~km}^{2}\right)$. But compared to most of the previous studies, Flanders is smaller in scale, more complex and intensive by nature. However, according to a rule of thumb, given by O'Neill [23], 25 ha is too small, as this rule states that a segments needs to be two to five times the investigated patch (in this case pasture parcels). Because the maximum patch area within the investigated municipalities was 21 ha, a segment size of 49 ha was chosen $(700 \times 700 \mathrm{~m})$. The number of segments was in each case study determined by a minimal area-cover of $10 \%$ of the total area. The location of the final segments is illustrated in Fig. 4 for the case study of Balen.

\subsubsection{Land use mapping}

Within each segment, the land use is mapped in detail on the field, based on aerial photographs from 2003, at scale 1:10,000. Pasture for horses is within the framework of this research the most important land use category to take into account. A pasture is considered to be used for horses if:

- Horses are present at the moment of mapping

- Typical horse-attributes are present, like ribbon fences

- Local inhabitants confirm that the pasture is used for horses

\subsubsection{Analysis of the fieldwork-data}

Spatial distribution and estimation of the area taken up by horses are analyzed using descriptive statistics to quantify the space used by horses in the different case studies. The results are translated to the scale of Flanders. Associations with environmental characteristics are investigated with logistic regression, adopted to 346 observations. Logistic regression is used for the prediction of the probability of the occurrence of an event (is there a horse present (1) or not (0)?). It makes use of several predictor variables (Table 1) that may be either numerical or categorical. Logistic regression is based on the odds, being the chance of 1 divided to the chance of 0 . The odds can vary from 0 to $+\infty$. The neperian logarithm of the odds or logit is taken to obtain values from $-\infty$ to $+\infty$ :

$$
\ln \left(\mathrm{p}_{1} / \mathrm{p}_{0}\right)=\mathrm{b}_{0}+\mathrm{b}_{1} \mathrm{X}_{1}+\mathrm{b}_{2} \mathrm{X}_{2}+\ldots+\mathrm{b}_{\mathrm{j}} \mathrm{X}_{\mathrm{j}}
$$

with $\ln \left(p_{1} / p_{0}\right)$ the logit; $b_{j}$ the value of the $j$ th coefficient, $j=0, \ldots, p ; X_{j}$ the value of the $j$ th independent variable; $b_{0}$ the intercept. 


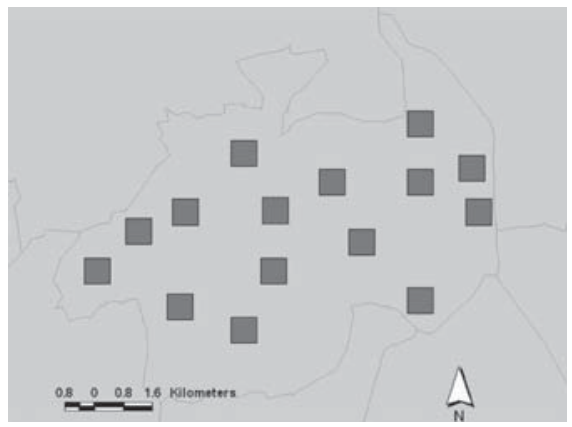

Figure 4: Example of a sample of square segments within the case study of Balen.

Table 1. Predictor variables used in the logistic regression.

\begin{tabular}{ll}
\hline Independent variable & \multicolumn{1}{c}{ Indicator } \\
\hline Proximity of gardens & $\begin{array}{l}\text { Euclidean distance to gardens (based on the topographic } \\
\text { land use map, NGI 2004) }\end{array}$ \\
Proximity of forest & $\begin{array}{l}\text { Euclidean distance to gardens (based on the forest mapping } \\
\text { by ANB, 2001) }\end{array}$ \\
Parcel area of pasture & $\begin{array}{l}\text { Parcel area (based on the fieldwork) } \\
\text { Perimeter/area of connected agricultural parcels per } \mathrm{km}^{2} \\
\text { Fragmentation of the } \\
\text { agricultural area }\end{array}$
\end{tabular}

Logit coefficients correspond to $\mathrm{b}$ coefficients in the logistic regression equation, the standardized logit coefficients correspond to beta weights. Goodness-of-fit tests such as Hosmer-Lemeshow and pseudo- $\mathrm{R}^{2}$ statistics are included as well as a validation of the model and indicators of model appropriateness, like the Wald statistic to test the significance of individual independent variables.

In logistic regression, multicollinearity should be avoided, because standard errors of the $b$ coefficients will be high and interpretations of the relative importance of the independent variables will be unreliable. To check for multicollinearity, the VIF statistic is used. When there is high multicollinearity, VIF will be high. When VIF is high, the $b$ and beta weights are unreliable and subject to misinterpretation. In general, multicollinearity is considered not to be a problem if VIF $\leq 2$ [12].

\subsection{Internet survey}

The goal of the internet survey was to get a better insight into (i) the motivation of people to keep one or more horses, (ii) the evolution of land use, due to horsification and (iii) identified problems to get the land people need for their horse(s).

\subsubsection{Context}

The census data and fieldwork, described above, bring in useful information to investigate the spatial distribution of horses and associations with environmental characteristics. However, these data do not tell us anything about the motivation of people to keep a horse. Also, the census data do not satisfy when evolutions have to be examined. Therefore, an internet survey for horse holders was set up. 
An important advantage of an internet survey is the low cost and the speed in which the survey can be distributed in different regions. Also the fact that answers are automatically saved in a database is an important plus, because this allows a faster automatic data processing [24, 25]. Moreover anonymity can be guaranteed and participation is totally voluntary. This makes the chances bigger to have more response [26]. Of course, internet surveys also have disadvantages. Examples are the limited availability of the internet for certain households, technical problems and the possibility of self-selection [27, 24]. Self-selection can be prevented by contacting people through more than one way. Another problem of internet surveys is the risk that people do not answer all the questions and related to this, the risk of a high 'drop out' (the phenomenon where people stop the survey without finishing it). Therefore, questions may not be too difficult or too long to read and the loading time may not be too long. A high drop out can also be prevented by holding out the prospect of a prize to the respondents $[28,26]$. A simple design, rather short questions, the use of 'jump blocks' and the prospect of a prize were used within this research to prevent a high drop out. Using jump blocks means that the respondent only has to fill in the questions that are relevant for him/her, depending on previous answers.

\subsubsection{Structure of the survey}

The survey was developed with the program Question Mark Perception 4 (QMP4). This program makes it possible to develop tests and surveys (anonym or not), using different types of questions: Multiple Choice, Multiple Response, Knowledge Matrix, Numeric, Fill in Blanks, Text Match and Essay. The survey consists of five main parts (the flowchart is given in Fig. 5). The first part deals with the present situation, the second part handles evolutions (in number of horses and land use) and the third part covers motivations as well as identified problems. The fourth part questions some socio-economic variables (like age and income) and finally, respondents are able to fill in further remarks in the fifth part. The server of the survey was connected to the domain registration: www.paardenenquete.be.

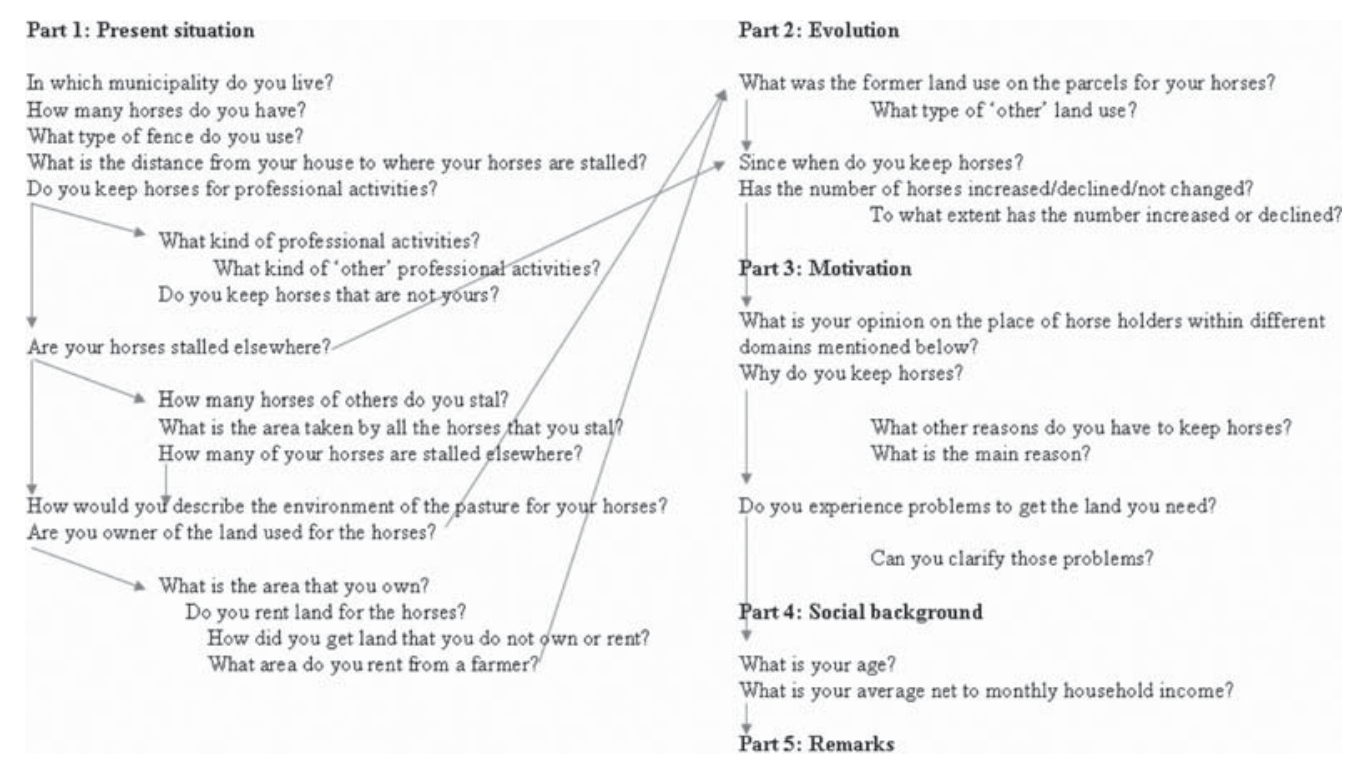

Figure 5: Flowchart of the internet survey. 


\subsubsection{A test version and distribution of the survey}

The survey was initially tested by 20 persons to optimize the design, content and understandability of the questions and to prevent technical problems when the survey is largely distributed. The useful remarks were included into a new version of the survey to improve its quality.

To ensure a wide distribution of the survey, horse holders were contacted through different ways:

- A total of 10 different authorities within the domains of horse riding, horse holding, horse breeding ... were contacted and asked to make know the link to the survey on their website or in their newsletter.

- The link to the survey was emailed to a list of maneges and horse holders.

- The link was sent to different contact persons to create a 'snowball-effect'.

\subsubsection{Analysis of the internet survey}

The official survey started on the 3rd of April 2009 and ended on the 6th of July 2009. The results from the survey were analyzed using the Reporter of the Perception Enterprise Manager of QMP4. The individual answers could be retrieved as well as a summary of the results. For a detailed analysis, results were exported to the excel format.

\section{RESULTS}

\subsection{An estimation of the spatial importance of horses}

Table 2 summarizes the area taken up by horses within the different case studies. An average is calculated for the different case studies as well as a weighed average, taking into account the area taken up by each cluster. The percentages in Table 5 have to be interpreted as a minimum, because it is possible that during the fieldwork, some pasture were not recognized to be pasture for horses.

When the average of $5.1 \%$ is translated to the level of Flanders, an area of 69,300 ha is taken up as pasture for horses. If an average density of 2 horses per ha is assumed (based on the internet survey and a density rule of the manure policy), the number of horses in Flanders is estimated to be at least 140,000. Therefore, the expert-estimation of 150,000 horses mentioned before seems to be a realistic one.

Table 2: Area taken up by horses within the different case studies.

\begin{tabular}{lccc}
\hline Case study & $\begin{array}{c}\text { Pasture for } \\
\text { horses/total area }(\%)\end{array}$ & $\begin{array}{c}\text { Pasture for horses/total } \\
\text { area open space }(\%)\end{array}$ & $\begin{array}{c}\text { Pasture for horses/total } \\
\text { area of pasture }(\%)\end{array}$ \\
\hline Balen & 6.6 & 9.7 & 39.6 \\
Lebbeke & 6.1 & 11.4 & 24 \\
Lendelede-Ledegem & 1.8 & 2.6 & 11 \\
Leuven & 2.1 & 4.9 & 36.1 \\
Lubbeek & 4.5 & 6.4 & 31 \\
Zoutleeuw & 5.2 & 6.2 & 27.1 \\
Average & 4.4 & 6.9 & 28.1 \\
Weighed average & 5.1 & 8.0 & 30.3 \\
\hline
\end{tabular}




\subsection{Associations with environmental characteristics}

The horse density per $\mathrm{km}^{2}$ and per $\mathrm{km}^{2}$ pasture is calculated for each cluster and summarized in Table 3. The average concentration of horses per $\mathrm{km}^{2}$ is the highest in the cluster that is characterized by urbanization, agricultural fragmentation and relatively low forest and pasture areas (1). The concentration is the lowest in the cluster that is characterized by cattle and horticulture (6) and in the cluster with mainly arable land, a low fragmentation and a low urbanization (3). Especially in the more fragmented, woody and urbanized clusters ( 1 and 4), the existing pastures seems to be more used by horses, compared to less urbanized clusters.

According to the logistic regression, based on the field work, a significant relationship is found between the presence of horses and parcel area, distance to gardens and distance to forest. The chance that a pasture parcel is used to keep horses is higher, the smaller the parcels and the smaller the distance to gardens and forest are. No multicollinearity was found between the independent variables, with VIF-values $<<2$ (Table 3 ). The output of the logistic regression is shown in table 4 . $\mathrm{R}^{2}$ is a measurement for the strength of association, but is generally low in logistic regressions (Table 4).

Table 3. Average horse density per $\mathrm{km}^{2}$ and per $\mathrm{km}^{2}$ pasture, per cluster.

\begin{tabular}{lcc}
\hline Cluster description & $\begin{array}{c}\text { Average number of } \\
\text { horses per } \mathrm{km}^{2}\end{array}$ & $\begin{array}{c}\text { Average number of } \\
\text { horses per km² pasture }\end{array}$ \\
\hline $\begin{array}{l}\text { 1. Urbanized, agricultural fragmentation, } \\
\text { relatively high forest and pasture areas }\end{array}$ & 10.1 & 80.9 \\
$\begin{array}{l}\text { 2. Mainly cattle and fodder crops, relatively } \\
\text { high forest areas }\end{array}$ & 8.4 & 63.1 \\
$\begin{array}{l}\text { 3. Mainly arable land, a low agricultural } \\
\text { fragmentation and urbanization }\end{array}$ & 6.2 & 45.0 \\
4. Strongly urbanized & 7.1 & 90.2 \\
5. Mainly fruit orchards & 6.7 & 65.1 \\
6. Mainly cattle and horticulture & 6.1 & 39.1 \\
\hline
\end{tabular}

Table 4. Multicollinearity test and outputs of the logistic regression.

\begin{tabular}{lcccccccc}
\hline $\begin{array}{l}\text { Independent } \\
\text { variable }\end{array}$ & Tolerance & VIF & B & S.E. & df & Sig. & $\operatorname{Exp}(\mathrm{B})$ & $\mathrm{R}^{2}$ \\
\hline $\begin{array}{l}\text { Fragmentation } \\
\begin{array}{l}\text { Distance to } \\
\text { forest }\end{array}\end{array}$ & -3.027 & 0.305 & -0.001 & 0.000 & 1 & 0.016 & 0.999 & Cox \& Snell: \\
$\begin{array}{l}\text { Distance to } \\
\text { gardens }\end{array}$ & -3.750 & 0.001 & -0.011 & 0.004 & 1 & 0.005 & 0.989 & $\begin{array}{l}0.197 ; \\
\text { Nagel-kerke: }\end{array}$ \\
$\begin{array}{l}\text { Parcel area } \\
\text { Constant }\end{array}$ & -4.311 & 0.000 & -1.207 & 0.317 & 1 & 0.000 & 0.299 & 0.263 \\
\hline
\end{tabular}


The Hosmer-Lemeshow (H-L) tests goodness-of-fit. If the $\mathrm{H}-\mathrm{L}$ statistic is greater than 0.05 , the null hypothesis 'that there is no difference between observed and model-predicted values' is not rejected, implying that the model's estimates fit the data at an acceptable level (Table 5).

To test the significance of each predictor variable in the model, the change in -2 Log Likelihood is used. When the significance of change is below 0.05 , the hypothesis that 'there is no effect of the predictor' is rejected. In this case, the three predictor variables have a significant influence (Table 6).

For validation, $70 \%$ of the observations were used to create the model, $30 \%$ for validation. According to Table 7, an overall percentage of $75 \%$ was predicted correctly (Table 7).

\subsection{Internet survey: horsification and motivation}

Almost 2,000 people started the survey, with a drop out of 48\%. 1,001 responses were useful for further analysis. The ages of the respondents varied from 10 to 72, with the majority around 25 and 45 years. 1/3rd of the respondents is younger than 30 .

\subsubsection{Number of horses and evolutions}

The total number of horses included in this survey is 3,564 (2,762 horses, 788 ponies, 14 donkeys). The majority of the respondents has $2-5$ horses (53\%) and $33.5 \%$ has only 1 horse (Fig. 6).

Table 5: Hosmer-Lemeshow statistic.

\begin{tabular}{lccc}
\hline Step & Chi-square & df & Sig. \\
\hline 3 & 8.370 & 8 & 0.398 \\
\hline
\end{tabular}

Table 6. Change in $-2 \log$ likelihood.

\begin{tabular}{lcccc}
\hline Variable & $\begin{array}{c}\text { Model log } \\
\text { likelihood }\end{array}$ & $\begin{array}{c}\text { Change in }-2 \text { log } \\
\text { likelihood }\end{array}$ & df & Sig. of the change \\
\hline Distance to forest & -141.433 & 6.166 & 1 & 0.013 \\
Distance to gardens & -142.716 & 8.733 & 1 & 0.003 \\
Parcel area & -148.694 & 20.688 & 1 & 0.000 \\
\hline
\end{tabular}

Table 7: Validation of the model.

\begin{tabular}{|c|c|c|c|c|c|c|c|c|}
\hline & & & \multicolumn{6}{|c|}{ Predicted } \\
\hline & & & \multicolumn{3}{|c|}{ Selected cases } & \multicolumn{3}{|c|}{ Unselected cases } \\
\hline & & & Hors & resent & Percentage & Hors & esent & Percentage \\
\hline \multicolumn{3}{|c|}{ Observed } & 0 & 1 & cor & 0 & 1 & correct \\
\hline \multirow[t]{3}{*}{ Step 3} & Horse present & 0 & 61 & 50 & 55.0 & 31 & 19 & 62.0 \\
\hline & & 1 & 26 & 101 & 79.5 & 8 & 50 & 86.2 \\
\hline & Overall perc & age & & & 68.1 & & & 75.0 \\
\hline
\end{tabular}




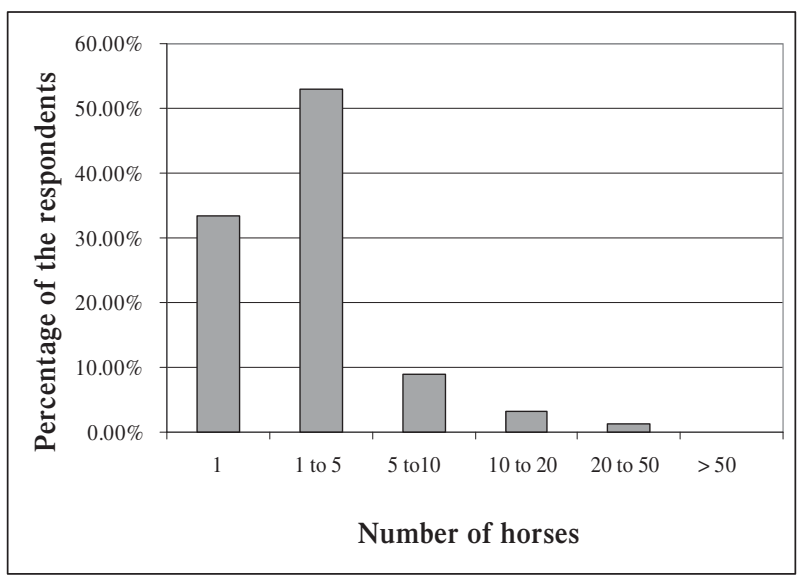

Figure 6: Frequency distribution of the number of horses per respondent.

The majority of the respondents keep horses since 1990 or later $(71 \%)$. More than $1 / 5$ th of the respondents $(21.1 \%$ ) keeps horses less than 5 years (since 2005 or later) (Table 8).

For most of the respondents, the number of horses increased (47\%) or remained unchanged (40\%). Only $10 \%$ talk about a decrease and $3 \%$ did not give a response. This trend of increase was also obtained $\left(\mathrm{R}^{2}=0.5808\right)$ when plotting the number of horses per respondent in 2005 against the number in 2009.

Most of the parcels that are now used as pasture for horses, were in the past pasture for cattle (29\%), pasture for horses of someone else (25\%) or arable land (20\%). Therefore, almost $50 \%$ of the present pastures for horses are certainly formal agricultural land (pasture for cattle or arable land). The results are summarized in Table 9.

\subsubsection{Motivation of horse holders and identified problems}

The majority of the respondents (86\%) keep horses as a hobby, only $12 \%$ keeps them for professional activities and $2 \%$ did not give a response.

Respondents were asked to fill in a matrix that checks to what extent horse holders see themselves as part of recreation, agriculture, nature, sport, commercial activities and cultural heritage (Table 10).

Sport and recreation seem to be the most important reasons to keep horses (99\% and 96\%). The fact that most of the people keep horses as a hobby corresponds to the fact that only $27 \%$ agrees with 'commercial activity'. It is striking that many horse holders see themselves linked with nature (41\%), while much less of them make this connection with agriculture (25\%). About $1 / 3 \mathrm{rd}(36 \%)$ see a link with cultural heritage.

Although an increase in area for horses was noticed in this survey, respondents also mentioned different problems they experience to gain sufficient land for their animals. The main reasons they quote for this are:

- Urbanization: residential areas or industry replace pasture areas

- The land is too expensive

- The presence of lots of other horse holders makes it more difficult to find land

- People do not want to rent their land because they hope the land will be converted to building land

- The agricultural holding act makes it impossible to compete for land against a farmer 
Table 8: Frequency distribution of the year when the respondents became horse owners.

\begin{tabular}{lc}
\hline Horse holder since $\ldots$ & Percentage \\
\hline $1900-1950$ & 0.23 \\
$1950-1960$ & 0.91 \\
$1960-1970$ & 2.61 \\
$1970-1980$ & 10.00 \\
$1980-1990$ & 15.23 \\
$1990-2000$ & 34.20 \\
$2000-2009$ & 36.82 \\
\hline
\end{tabular}

Table 9: Land use changes due to horsification.

\begin{tabular}{lcc}
\hline Former land use & Percentage & $\begin{array}{c}\text { Number of } \\
\text { respondents }\end{array}$ \\
\hline Pasture for horses of someone else & 25.37 & 220 \\
Pasture for cattle & 29.30 & 254 \\
Arable land & 20.42 & 177 \\
Fallow & 11.07 & 96 \\
Other land use* & 10.50 & 91 \\
No response & 3.34 & 29 \\
\hline
\end{tabular}

*Other land use, mentioned by a few respondents, includes space for sheep (17 respondents), garden (16), fruit orchard (14), meadow (6), building land (5), vegetables (3), space for chicken (3), forest (2), recreation area (2), space for pigs (1), greenhouse (1), tree cultivation (1) and a florist business (1).

Table 10: Horse holders' opinion on their place within different domains.

\begin{tabular}{lccccccc}
\hline \multirow{2}{*}{ Domain } & $\begin{array}{c}\text { Totally } \\
\text { agree }\end{array}$ & Agree & Not agree & agree & Total & $\%$ Agree & \% Not agree \\
\hline Recreation & 798 & 128 & 8 & 4 & 938 & $98.72 \%$ & $1.28 \%$ \\
Agriculture & 45 & 130 & 163 & 361 & 699 & $25.04 \%$ & $74.96 \%$ \\
Nature & 86 & 204 & 114 & 300 & 704 & $41.19 \%$ & $58.81 \%$ \\
Sport & 652 & 228 & 12 & 23 & 915 & $96.17 \%$ & $3.83 \%$ \\
Commercial & 53 & 140 & 156 & 361 & 710 & $27.18 \%$ & $72.82 \%$ \\
activity & & & & & & & \\
Cultural heritage & 81 & 172 & 142 & 310 & 705 & $35.89 \%$ & $64.11 \%$ \\
\hline
\end{tabular}


- Farmers do not rent or sell their land because:

They need the land themselves for production

They receive subsidies to leave the land fallow

They need their land in the framework of manure policies

They hope the land will be converted to building land

They think horses damage the land too much

- Rules in Flemish spatial planning policy makes expansion often difficult

\section{DISCUSSION AND CONCLUSION}

In this paper, different information sources were combined: census data, field samples and an internet enquiry. The internet survey applied, cannot just be considered as yielding a statistically representative sample of Flanders, but the high number of respondents $(1,001)$ makes the results very useful for interpretation of the horsification phenomenon. Next to new quantitative, temporal and spatial information this survey essentially yielded qualitative information about motivations.

The conclusions drawn from the different information sources are similar, concerning the geography and the evolution of the use of pastures for horses. The amount of space, used for horses in Flanders was estimated to be at least 69,300 ha. This is higher than a previous estimation by Viaene et al. [4]. The area corresponds to about one-third of the grassland in Flanders and therefore horses take up a significant part of the open space. The average horse density per cluster clearly depicts a spatial relation with urbanisation and a fragmented agricultural area. This was also mentioned by Van de Sype [29] who noticed a high number of horses in the fragmented Flemish municipality of Sint-Katelijne-Waver, where significant areas of vegetables were transformed to pasture for horses.

Because horses mainly replace former agricultural activities, areas with a more stable and less fragmented agricultural sector are characterized by less pasture for horses. At the scale of a parcel, the logistic regression showed significant associations with the distance to gardens and forest areas and with the parcel area. Small pasture parcels at a low distance to gardens and to forest areas have a higher chance to be pasture for horses. Van der Windt [9] also pointed to the small scale of parcels with horses in the Netherlands. Because gardens are mainly associated with urban and semi-urban areas [30], the results per cluster, where the more urbanized clusters show a higher concentration of horses, are confirmed. Also Myhr and Johansson [2] and Verburg et al. [1] talk about this relation with urbanized areas.

Horse keeping and grazing has physical and managerial characteristics of animal husbandry in agriculture. Therefore, it could be considered as one compartment of agriculture. However, unlike the period before the '60s of former century, when horsekeeping was predominantly linked to agriculture the essential motivation for people to keep horses nowadays is linked to sport, free time and recreation. It was striking that the majority of the respondents do not see themselves to be part of the agricultural sector. Horsification is clearly an evolution that cannot be considered as an agricultural one, despite the physical and ecological similarity of this with farming grazing systems. In the internet survey, the respondents made explicit that their social and cultural linkage to agriculture is low. At the contrary, there is rather a competition with agriculture, essentially in matters of acquisition and preservation of land.

In the current land use planning system in Flanders, the dichotomy of urban versus rural areas is explicitly maintained, despite the strong degree of peri-urbanisation. Furthermore and within the rural areas, the practice of land use planning essentially boils down to the quantitative allocation of land to the two major 'official' stakeholders: agriculture and nature conservation, and design it in such way that further spatial fragmentation is minimized for both functions. Other functions and 
services are considered rather as modulations and complements to the major destinations. Horsification can be seen as a phenomenon that crosses the current principles of land use planning in different ways and it is strongly linked to the fringe of urban and residential areas. These areas decreasingly match the model image of segregated urban and rural areas, giving fuel to the concept that semi-urban areas should be considered as plan areas in their own right [31]. Within these transition areas, horsekeeping adds not only to the preservation of open space, but also to the fragmentation of land: farmers find it harder to assemble or maintain cohesive field clusters and moreover suffer from raising prices in a fiercely competitive land market. Given the divide between horsekeeping stakeholders and farming, in lesser degree also forestry and nature conservation, horsekeeping should be considered as a complementary sector of open space, despite the legitimate interpretation that it also is some form of 'soft urbanisation', since spatially and functionally linked to residential areas, and a consumer of space in competition with the more traditional rural sectors.

How then should land use planning proceed in order to provide space for bottom-up generated demands such as horsekeeping as a specific subsector of open air recreation whilst at the same time safeguarding and enhancing demands for long-term sustainability and multifunctionality? There is a risk to remain stuck in traditional and generic ideas on how to allocate and manage open space. In addition to the desirability of preserving existing landscape identity, the protection of existing elements, space and functions should not blindly rule out the possibility of new developments emerging with new values [32]. A more creative planning - taking into account structures, functions and values, different from the traditional ones - could face the challenge that we have to decide how much traditional landscape and land use functions we will take in future [33]. Therefore, region-specific and integrated design projects are of growing importance in developing the open space in a sustainable way. Design has the capacity to strengthen this creative aspect of planning as it is more directed towards transformation and creation of new landscapes. The major design challenges within the context of this paper are (i) to avoid increasing functional and spatial fragmentation of rural landscapes, (ii) to assure enough space for societal necessity urgencies such as food or energy self efficiency, (iii) to increase positive interactions of horse keeping with other sectors such as agriculture, nature conservation and others and (iv) to develop a proper visual and cultural landscape strategy, helping in setting up guidelines for fencing and other infrastructural elements that do not deteriorate the landscape character. More research on the environmental impact of horsification is necessary to take up these challenges.

\section{REFERENCES}

[1] Verburg, P.H., van de Steeg, J., Veldkamp, A. \& Willemen, L., From land cover change to land function dynamics: a major challenge to improve land characterization. Journal of Environmental Management, 90(3), pp. 1327-1335, 2009. doi:10.1016/j.jenvman.2008.08.005

[2] Myhr, U. \& Johansson, R., EcoEffect for outdoor environments, the process of tool development. Environmental Impact Assessment, 28(7), pp. 439-454, 2008. doi:10.1016/j.eiar.2007.09.001

[3] Saifi, B. \& Drake, L., Swedish agriculture during the twentieth century in relation to sustainability. Ecological Economics, 68(1-2), pp. 370-380, 2008. doi:10.1016/j.ecolecon.2008.04.003

[4] Viaene, J., Gellynck, X. \& De Belder, T., Het economische belang van de paardensector. Universiteit van Gent. Faculteit landbouw en toegepaste biologische wetenschappen. In opdracht van de Belgische Confederatie van het Paard, pp. 1-78, 2003.

[5] Policy Research Cooperation. De paardensector als economische en maatschappelijke actor in Vlaanderen. Een analyse van het economische en sociaal-maatschappelijke profiel en belang van de Vlaamse paardenhouderijen. Presentation Workshop, Brussels, 16th October 2008. 
[6] Törn, A., Tolvanen, A., Norokorpi, Y., Tervo, R. \& Siikamäki, P., Comparing the impacts of hiking, skiing and horse riding on trail and vegetation in different types of forest. Journal of Environmental Management, 90(2009), pp. 1427-1434, 2009.

[7] Busck, A.G., Kristensen, S.P., Prøstholm, S. \& Primdahl, J., Porous landscapes - the case of greater Copenhagen. Urban Forestry \& Urban Greening, 7(3), pp. 145-156, 2008. doi:10.1016/j.ufug.2007.05.002

[8] Vlaamse Landmaatschappij(VLM). 7 dialoogdagen over depaardenhouderij-Discussieteksten en verslagen. Een initiatief van Vlaams minister-president Kris Peeters. Vlaamse Landmaatschappij. VU Guido Clerx, 2009. Available online: www.vlm.be.

[9] Van der Windt, N.P., Olde Loohuis, R.J.W. \& Agricola, H.J., De paardenhouderij in beeld, een verkenning naar de landschappelijke verschijningsvorm van de paardenhouderij. Alterra-rapport 1444. Wageningen: Alterra, 2007.

[10] Vejre, H., Models for safeguarding urban fringe open landscapes the balance between public and private. Case study of management models for urban green space around Copenhagen. Proc. of the Conference 'Rurality Near the City', eds. V. Dewaelheyns \& H. Gulinck, KULeuven: Leuven, pp. 51-60, 2008. Available online: www.ruralitynearthecity.be

[11] Daniels, T.L., Hobby farming in America: rural development or threat to commercial agriculture? Journal of Rural Studies, 2(1), pp. 31-40, 1986. doi:10.1016/0743-0167(86)90071-9

[12] Norusis, M.J., SPSS 15.0. Statistical Procedures Companion, Prentice Hall, New Jersey, 2006.

[13] Food and Agriculture Organisation of the United Nations (FAO), Statistical Development Series 1996: Conducting Agricultural Censuses and Surveys. Rome, 1996.

[14] Gallego, F.J., Sampling Frames with Square Segments. Office for official publications of the European Communities: Luxembourg, 1995.

[15] Tsiligirides, T.A., Remote sensing as a tool for agricultural statistics: a case study of area frame sampling methodology in Hellas. Computers and Electronics in Agriculture, 20(1998), pp. 45-77, 1998.

[16] Cotter, J. \& Nealon, J., Area Frame Design for Agricultural Surveys, National Agricultural Statistics Service, USDA: Washington, 1987.

[17] Bunce, R.G.H., Metzger, M.J., Jongman, R.H.G., Brandt, J., De Blust, G., Elena-Rossello, R. et al., A standardized procedure for surveillance and monitoring European habitats and provision of spatial data. Landscape Ecology, 23(1), pp. 11-25, 2007. doi:10.1007/s10980-007-9173-8

[18] Cooper, A. \& en McCann, T., Habitat Change in the Northern Ireland Countryside: Summary Report of the Northern Ireland Countryside Survey, 2000. Environment Heritage Service, Department of the Environment for the Northern Ireland, Belfast, 2002.

[19] Gallego, F.J., Crop area estimation in the MARS project. Conference on Ten Years of the MARS Project, Brussels. Agriculture and Regional Information Systems, Space Applications Institute, JRC, Italy, 1999.

[20] Bunce, R.G.H., Howard, D.C.J., Hallam, C.J. \& Benefield, C.B., Ecological Consequences of Land Use Change. Final Report to Department of Environment, Institute of Terrestrial Ecology, Cumbria (UK), 1992.

[21] Sepp, K., The Methodology and Applications of Agricultural Landscape Monitoring in Estonia. Vol. 9. Dissertationes Geographicae Universitatis Tartuensis, Tartu University Press, Tartu. 167 pp, 1999.

[22] Rondeux, J.E., Bauffe, C., Boreux, D. \& Dawant, J.M., Mise au point d'une méthodologie d'inventaire des habitats dans le cadre du suivi de la biodiversité en Région Wallone, Faculté Universitaire des sciences agronomiques de Gembloux, Unité de Gestion et Economie forestières, 1999. 
[23] O’Neill, R.V., Hunsaker, C.T., Timmins, S.P., Jackson, B.L., Jones, K.B., Riiters, K.H. \& Wickham, J.D., Scale problems in reporting landscape pattern at the regional scale. Landscape Ecology, 11(3), pp. 169-180, 1996. doi:10.1007/BF02447515

[24] Malhotra, N.K. \& Birks, D.F., Questionnaire design. Marketing Research: an Applied Orientation, Pearson Education Limited, pp. 324-331, 2003.

[25] Roth, M., Validating the use of internet survey techniques in visual landscape assessment - an empirical study from Germany. Landscape and Urban Planning, 78(3), pp. 179-192, 2006. doi:10.1016/j.landurbplan.2005.07.005

[26] Reips, U.D., The Web-experiment Method: Advantages, Disadvantages and Solutions, Academic Press: San Diega, CA, pp. 89-114, 2000. doi:10.1026//1618-3169.49.4.243

[27] Reips, U.D., Standards for internet-based experimenting. Experimental Psychology, 49(4), pp. 243-256, 2002.

[28] Bächtiger, M., Frick, A. \& Reips, U.D., Financial Incentives, Personal Information and Dropout in Online Studies, Pabst Science: Lengerich, Germany, pp. 209-219, 2001.

[29] Van de Sype, P., Drijvende krachten van landgebruiksveranderingen in Sint-Katelijne-Waver. Eindwerk aan de Katholieke Universiteit van Leuven, Departement aard- en omgevingswetenschappen, afdeling bos, natuur en landschap, p. 105, 2008.

[30] Dewaelheyns, V., Bomans, K. \& Gulinck, H., Verspreiding, morfologie en ruimtelijke associaties van het tuincomplex in Vlaanderen. Ad Hoc Opdracht voor Steunpunt Ruimte en Wonen. In opdracht van Departement Ruimte, Wonen en Onroerend Erfgoed, Brussel, pp. 1-138, 2008.

[31] Meeus, S. \& Gulinck, H., Semi-urban areas in landscape research: a review. Living Reviews in Landscape Research, 2(2008), p. 3, 2008. Available online: http://www.livingreviews.org/ lrlr-2008-3.

[32] Krause, C.L., Our visual landscape - managing the landscape under special consideration of visual aspects. Landscape and Urban Planning, 54(1-4), pp. 239-254, 2001. doi:10.1016/S0169-2046(01)00139-6

[33] von Haaren, C., Landscape planning facing the challenge of the development of cultural landscapes. Landscape and Urban Planning, 60(2), pp. 73-80, 2002. doi:10.1016/ S0169-2046(02)00060-9 